\title{
How local communities attribute livelihood vulnerabilities to climate change and other causes: a case study in North Vanuatu
}

\author{
Danny Philipp Nef ${ }^{1}$ (D) - Daniel Neneth ${ }^{2} \cdot$ Patteson Dini ${ }^{3} \cdot$ Carmenza Robledo Abad ${ }^{1}$. \\ Pius Kruetli ${ }^{1}$
}

Received: 28 October 2020 / Accepted: 10 September 2021 / Published online: 17 October 2021

(C) The Author(s) 2021

\begin{abstract}
Understanding the causal factors of livelihood challenges and associated vulnerabilities is essential for developing viable adaptation strategies. However, clarifying which livelihood challenges can be attributed to which causal factors remains a challenge. In this paper, we used a case study in Vanuatu to show how local populations attribute subsistence challenges to underlying causes. Particularly, we are interested in whether there is a tendency to view climate change as the primary cause, and if so, why. We followed a participatory approach involving local community members and experts at all stages of the study process. For this, we used complementary research methods such as resource mapping, participant observation, and in-depth interviews with local community members and local agriculture experts. The results show that local populations are indeed inclined to attribute problems to external causes, particularly climate change. However, the results also indicate that this external attribution is not definitive. Rather, we find that over the course of participatory reflection, attribution to climate change was supplemented and even replaced by internal causal factors, such as changes in garden practices. Our findings suggest that the initial emphasis on climate change may be related to prevailing narratives that may have influenced individual perceptions of the study participants and created social desirability. If such bias is not recognized, the narratives risk being reified, with potential new insights being overlooked. As a result, local attribution may overstate or understate specific causes, such as climate change.
\end{abstract}

Keywords Climate change $\cdot$ Local knowledge $\cdot$ Local perception $\cdot$ Local attribution Social desirability bias $\cdot$ Livelihood vulnerability

Danny Philipp Nef

danny.nef@usys.ethz.ch

1 Department of Environmental Systems Science, Institute for Environmental Decisions, ETH

Zürich, Universitätstrasse 16, 8092 Zürich, Switzerland

2 Department of Agriculture, Sola, Vanuatu

3 Mota Lava's Kastom Society, Mota Lava, Vanuatu 


\section{Introduction}

Similar to many other small island developing states (SIDS), Vanuatu is considered highly vulnerable to global change, particularly climate change (Connell 2015; Lowitt et al. 2015). The country has a limited capacity to respond to these stressors (Feeny et al. 2013). In North Vanuatu, the majority of the food and the income is derived from perennial gardens and terrestrial and marine ecosystems (Vanuatu National Statistics Office [VNSO] 2009). This reliance on natural systems can leave local communities particularly vulnerable to the effects of climate change, as the physical, biological, and biophysical impacts on these systems directly translate into consequences for agricultural production and thus food security and income (Food and Agriculture Organization of the United Nations [FAO] 2016). Forward-looking assessments by government agencies and non-governmental organizations (NGOs) forecast significant disruptions in food production in the Pacific in light of the anticipated aggravation of climatic conditions, such as changes in precipitation, surface air, or sea temperature (Department of Agriculture and Rural Development - Vanuatu [DARD] 2017; FAO 2010; IPCC 2012; National Advisory Committee on Climate Change [NACCC] 2007).

In addition to climate change, several sociocultural and economic factors can affect either agricultural productivity or income, sometimes causing or increasing local livelihood vulnerability (Feeny et al. 2013; McGregor et al. 2009). In particular, rising food prices can have significant effects on household budgets, as food purchases account for more than half of household expenditures, even in the country's rural areas (Vanuatu National Statistics Office [VNSO] 2012), where most of the food is still derived from subsistence farming (McGregor et al. 2009). Furthermore, increasing fuel prices affect transportation costs and thus the cost of delivering goods to markets (Feeny et al. 2013). A number of authors have explicitly highlighted the importance of understanding the causal drivers of changes in natural and human systems as a prerequisite for developing policies and strategies aimed at reducing vulnerability (IPCC 2014a; Ribot 2010, 2014). This is challenging because these drivers interact across multiple temporal and spatial scales, making it difficult to attribute effects to single root causes (IPCC 2014b).

Despite the wealth of the literature on how local communities experience vulnerability and the extent to which this is aligned with climate change scenarios or ongoing changes, little attention has been paid to the process of how local actors attribute livelihood challenges and associated vulnerabilities to specific causes (Dorward et al. 2020; Mertz et al. 2009; Rao et al. 2011). Aiming to contribute to filling this gap, in this study, we go beyond examining perceived livelihood challenges and associated vulnerabilities (hereafter, livelihood vulnerabilities) and identify internal or external potential causes in a participatory manner using a case study in North Vanuatu. Besides identifying potential causes of vulnerability, we explore how local populations attribute the causes of livelihood vulnerabilities to external and/or internal phenomena and what factors might influence this attribution. We are especially interested in whether, and if so, why, the local population tends to consider climate change as the main or sole cause of current livelihood vulnerabilities. A potential overemphasis on climate change may hinder the recognition of other causes of vulnerability (Allen and Bourke 2009).

We acknowledge previous work explaining the importance of local knowledge for understanding the dynamic interactions between global changes, such as climate change, and overall vulnerability at the local level (Dorward et al. 2020; IPCC 2014a; Lefale 2010; McNamara and Prasad 2014). Furthermore, we support the view that considering 
local knowledge and needs in analyzing the causes of vulnerability can increase the relevance of the results and the feasibility of recommendations (Ribot 2010). As for Vanuatu, local knowledge is increasingly perceived as an important source of knowledge, especially for building adaptive capacity regarding climate change (Granderson 2017; Mondragon 2018). The potentially important role of local knowledge in vulnerability assessments has prompted many case studies in the Pacific and elsewhere that examine farmers' perceptions of climate change and illustrate the value of local knowledge for designing viable adaptation strategies (e.g., Blair and Momtaz 2019; Lefale 2010; McNamara and McNamara 2011; McNamara and Prasad 2014; Mertz et al. 2009; Warrick 2011). The question of the accuracy of farmers' perceptions is the focus of many of these studies (Ayanlade et al. 2017; Howe et al. 2013; Rao et al. 2011; Reyes-Garcia et al. 2016; Swim et al. 2009). Thus, the goal of this study is explicitly not to evaluate the accuracy of local knowledge underlying attribution by contrasting it to scientific knowledge.

For the purpose of our study, we characterize local knowledge based on Mercer and colleagues' (2010) argument that it represents a body of knowledge acquired by local people over time through the "accumulation of experiences, society-nature relationships, community practices, and institutions." Thus, local knowledge has an important social dimension. People share knowledge and apply it collectively, but not always in the same way and sometimes even in contradictory ways (Setten and Lein 2019). Therefore, local knowledge has both a collective and an individual character. People may experience, interpret, and use knowledge differently and/or have specialized knowledge acquired through training or access to non-local sources, such as global media content or awareness campaigns. We hypothesize that attribution of livelihood vulnerabilities to possible causes using local knowledge is subject to the same dynamics. These dynamics make the question of the attribution process and the underlying knowledge particularly interesting yet methodologically challenging. In Vanuatu as well, local knowledge and thus local attribution are subject to constant changes through various initiatives and awareness-raising campaigns by government and NGO programs.

The use of the term "vulnerability" in this study refers to the World Food Programme's (2004) definition of it "as being composed of two principal components, namely [the] i) risk of exposure to different types of shock or disaster events [...] [and the] ii) ability of the population to cope with different types of shock or disaster events." For our research in Vanuatu, this definition allowed us to take a multi-factorial approach to understanding vulnerability drivers, including climate change and other factors, and to include the capacity to cope with the shocks occurring in SIDS in the Pacific (Guillaumont 2010).

\section{Methods and procedure}

The case study took place in eleven rural communities on five islands of the Banks Group in North Vanuatu (Fig. 1). The climate of the Banks Islands is tropical, with an average annual temperature of $26.8{ }^{\circ} \mathrm{C}$ and rainfall around $4000 \mathrm{~mm}$ per year. During the cooler and dryer southern winter (May-September), trade winds from the southeast prevail with an average of ten knots. During summer (October-April), the weather is warm and mostly calm with light winds from the southeast (Cillaurren et al. 2001). The islands considered in this study differ considerably from one another regarding topography and economic development (Online Resource 1). For example, transport infrastructure has widely varying impacts on the economic strategies practised at livelihood level. While people on islands 


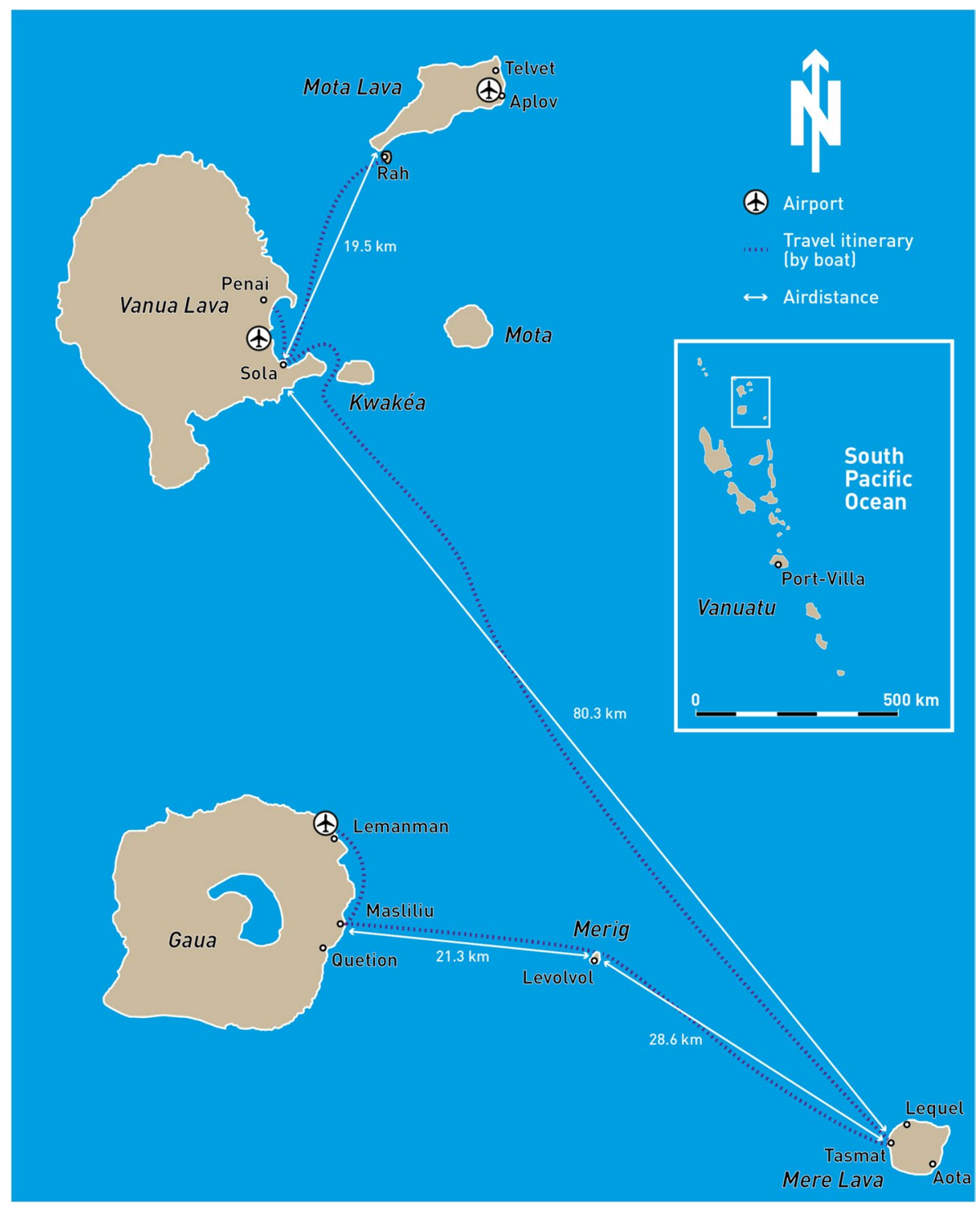

Fig. 1 Map of study area with villages where interviews and workshops took place. Illustration: S. Bösch, ETH Zurich

without proper transport are isolated and remain dependent on subsistence economic activities (e.g., Mere Lava and Merig), people from islands with better developed infrastructure are connected to markets where they sell local products and/or are engaged in tourism (e.g., Gaua or Mota Lava).

For the conceptual framing of our study, we followed the "model of transdisciplinarity" proposed by Jahn et al. (2012), which essentially comprises three phases: (1) problem transformation; (2) production of new knowledge; and (3) transdisciplinary integration 
(see also Pohl et al. 2017). The first phase implies combining a scientific problem with the societal problem into a common research objective. The definition of the societal problem is based on the findings of ethnographic research on local traditional resource management conducted by the main author during two field visits of 6 and 4 months in 2016 and 2018 , respectively. The insights gained from this study were analyzed using current climate change and livelihood vulnerability views from the scientific perspective in a joint process with local agricultural experts and members of local communities. This way we formed a common research goal and developed the tentative research design for this study. Participatory problem definition enabled local needs to be incorporated into the research question and ensured the relevance of the findings to the local population. In addition, it enabled the identification of prevailing narratives (both from the researchers and the local population) from the outset.

The second phase focused on the production of new knowledge (see Online Resource 2 for analytical framework). We first investigated the effects and impacts of climate change and the characteristics of local livelihoods. The field trip for collecting local knowledge and perceptions took place between May and June 2019. We used semi-structured interviews, workshops with participatory methods (resource mapping and drawing of annual farming calendars), and ethnographic interviews.

Ethnographic interviews differ from semi-structured interviews in that they do not take place in a formal setting, but in a naturalistic setting (Allen 2017), in our case, the farmers' gardens. The goal of the interviews was to explore the meanings that farmers ascribed to actions and events, i.e., farming practices, in their own words at an individual or household level and in a setting that also allowed them to visually demonstrate what they were saying (Roulston 2010, p. 86). We used complementary research methods for two reasons. First, workshops in complement to face-to-face interviews allowed us to jointly analyze findings from the two lines of interest: climate change and livelihoods. The main aim of this analysis was to find convergences and divergences in the perceptions of climate change as a possible factor affecting food production and income generation from food products. Second, the use of different settings (presence of others versus face-to-face) helped to make visible the use of different types of knowledge and to differentiate the extent to which responses vary by social setting, i.e., if and how the answers vary if respondents are alone or in a discussion with other members of the community. Although other methods exist to identify reasons for variation in responses or interpretation (Fisher and Tellis 1998; Grimm 2010), the combination of methods used corresponds well to the contextual conditions in northern Vanuatu, especially considering local linguistic and cultural realities.

The participatory process also aimed to enable transdisciplinary integration, the last step in the model proposed by Jahn et al. (2012). Specifically, this integration aimed to evaluate the emerging knowledge for its contribution to the social and scientific process, thus enabling social learning and empowerment among local actors (Fazey et al. 2010; Jahn et al. 2012). Furthermore, it allowed to increase the results' robustness through triangulation (Creswell and Miller 2000). Particularly, we encouraged reflection about insights emerging during the previous phases by facilitating discussions between researchers, local agricultural experts, and community members through workshops and informal meetings. An additional plausibility analysis was conducted by reflecting on the results of the workshops with local experts, thus allowing us to triangulate and increase the robustness of the results (Creswell and Miller 2000).

We interviewed a stratified random sample of three to twenty residents per island. In total, we interviewed 44 people, half of whom were women. Besides gender, interviewees were selected according to age, with the youngest interviewee being 24 and the oldest 92 . 
The interview covered three main topics: livelihood strategies and the problems associated with pursuing them, the perception of climate change and its effects, and the characteristics of local well-being. Each interview lasted between 45 and $90 \mathrm{~min}$. The interview guide, a set of instructions and questions, was tested on Mota Lava with two farmers and one agricultural officer to adapt content and comprehensibility for interviewees where necessary.

The research team visited 13 gardens together with their owners, each located in a different village. We used these informal settings for ethnographic interviews, framing the topic around management practices by asking descriptive questions, such as "Could you describe the different crops that you have planted?".

After completing all interviews, workshops were conducted on all islands except Merig, meaning four workshops, with a total of 65 participants, 31 women and 34 men. These workshops aimed to identify the convergences and divergences in vulnerability factors participatorily. We used the snowball sampling technique to recruit workshop participants from the circle of acquaintances of interviewees (Goodman 1961). We neither restricted the number of persons recruited nor excluded the interviewees themselves from participation. At the beginning of each workshop, we facilitated gender-specific resource mapping sessions to understand how residents access and control resources, whether differences exist between women and men (Chambers 2006), and for which of these resources the participants identify climate change impacts. These sessions helped facilitate discussion both within each gender-specific group and between the two groups. Participants then discussed how they perceived climate change and assessed its effects. Subsequently, the findings were transferred to an annual agricultural calendar that participants drew based on the applied gardening practices (e.g., planting time of different crops). After local agriculture experts had complemented the calendar with official recommendations, the research team facilitated a plenary discussion on the causal relationships between management practices, the effects of climate change, and the perceived difficulties of pursuing livelihood strategies.

Interviews and workshops were conducted either in English, in Bislama, the lingua franca of Vanuatu, or in one of the four island-specific vernacular languages. In the latter case, the answers were translated simultaneously by a local research partner into English or Bislama.

We produced a summarizing protocol, a technique proposed by Mayring (2002), where the recorded information is paraphrased during transcription (pp. 94-98). The qualitative analysis explored the approach presented by Ritchie et al. (2003) and comprised three main steps: (1) data management (building a thematic framework), (2) descriptive accounts, and (3) explanatory accounts (pp. 220-248). The first step was guided by a series of questions adapted from Böhm (2012, pp. 477-478). These questions helped us become familiar with the data, identify initial themes or concepts, and create an index. This served as a basis for building an initial thematic framework, which we then used to code (index) the data and conduct the iterative process of descriptive analysis. This analysis primarily defined categories, classified the data, and refined the thematic framework where necessary. Based on these findings, we conducted an associative analysis (explanatory accounts) to identify relationships between the identified phenomena.

\section{Results}

\subsection{Findings on livelihood strategies and associated challenges}

We used the term livelihood strategy as "an organised set of lifestyle choices, goals, and values, and activities influenced by biophysical, political/legal, economic, social, cultural, and psychological components" (Walker et al. 2001). 


\subsubsection{Subsistence gardens and cash crop plantations}

Gardening with no permanent cash crops forms the backbone of livelihood strategies on the Banks Islands. Across all the communities surveyed, gardens were the most important source of food and income (Table 1). There were, however, some regional differences. While gardens were mentioned in interviews and workshops as by far the most important source of food especially on remote islands such as Mere Lava and Merig, small shops have partially dominated this role in islands with better transport infrastructure and thus access to markets, like Vanua Lava or Mota Lava. Shops were further favored because gardens can be far away from settlements, meaning that harvesting activities were associated with high expenditures of time and/or money. In principle, this affects mostly elderly people with health restrictions. However, also younger people increasingly prefer small shops over private gardens as a more accessible source of food. In addition to age, gender also affects assessments of the importance of gardening as a livelihood strategy. While 23 out of 44 interviewees, both men and women, stated in interviews that a large part of their income is derived from the sale of unprocessed garden products, only women earned additional income from processing crops and selling the resulting products at local markets or during festivities (32\%, 7 out of 22 women). The resource mapping also showed that gardens can be a more important income source for women than for men.

Local gardens have a rich variety of cultivated plants. Thirty-six different crops were mentioned during the interviews, with nine species per garden in average. Six crops were regarded as particularly important for both food and income (Table 1): yam, banana, island cabbage, manioc, sweet potato, locally known as kumala, taro fiji, and island taro (see Online Resources 3 for details on species and taxonomy). Although practically every household grows papaya for private consumption, the fruit tree was mentioned by only a few respondents, possibly because papayas grow around their houses, not in the gardens.

Table 1 Food and income source with challenges encountered. The table shows the number of study participants using a particular good from a particular source and the importance of this good for food and income. The figures represent the number of mentions in interviews $(N=44$, multiple answers possible). Importance: $1=$ low importance (irregular income); $2=$ important (regular income); $3=$ very important (regular income). No. of goods for $\mathrm{F}=$ food source; $\mathrm{I}=$ income; $\mathrm{T}=$ total. (Information derived from interviews)

\begin{tabular}{|c|c|c|c|c|c|c|c|c|c|c|c|c|c|}
\hline \multirow{9}{*}{$\begin{array}{l}\text { Source } \\
\text { Gardens }\end{array}$} & \multirow{9}{*}{$\begin{array}{l}\begin{array}{l}\text { Challenges } \\
\text { encountered }\end{array} \\
\begin{array}{l}\text { Decreasing } \\
\text { productivity }\end{array}\end{array}$} & \multicolumn{3}{|c|}{ No. of goods } & \multirow[t]{3}{*}{ Most mentioned goods } & \multicolumn{4}{|c|}{ Food Source } & \multicolumn{4}{|c|}{ Income Source } \\
\hline & & \multirow[t]{2}{*}{$\mathrm{F}$} & \multirow[t]{2}{*}{ I } & \multirow[t]{2}{*}{$\mathrm{T}$} & & \multirow[t]{2}{*}{$\begin{array}{l}\text { Total } \\
(N=44)\end{array}$} & \multicolumn{3}{|c|}{$\begin{array}{c}\text { Importance } \\
\text { No. of mentions }\end{array}$} & \multirow[t]{2}{*}{$\begin{array}{l}\text { Total } \\
(N=44)\end{array}$} & \multicolumn{3}{|c|}{$\begin{array}{c}\text { Importance } \\
\text { No. of mentions }\end{array}$} \\
\hline & & & & & & & 1 & 2 & 3 & & 1 & 2 & 3 \\
\hline & & 35 & 33 & 36 & Yam & 43 & 5 & 11 & 27 & 27 & 9 & 16 & 2 \\
\hline & & & & & Banana & 42 & 10 & 21 & 11 & 20 & 8 & 9 & 3 \\
\hline & & & & & Island Cabbage & 41 & 14 & 6 & 21 & 19 & 7 & 8 & 4 \\
\hline & & & & & Manioc & 38 & 7 & 19 & 12 & 18 & 13 & 4 & 1 \\
\hline & & & & & Kumala & 36 & 12 & 14 & 10 & 17 & 6 & 8 & 3 \\
\hline & & & & & Fijian/Island taro & 21 & 5 & 7 & 9 & 12 & 7 & 3 & 2 \\
\hline \multirow{4}{*}{$\begin{array}{l}\text { Marine } \\
\text { resources }\end{array}$} & \multirow{4}{*}{$\begin{array}{l}\text { - Depletion } \\
\text { - Accessibility }\end{array}$} & 16 & 14 & 23 & shallow water reef fish & 36 & 17 & 15 & 4 & 19 & 7 & 11 & 1 \\
\hline & & & & & Molluscs & 35 & 21 & 14 & 0 & 11 & 7 & 4 & 0 \\
\hline & & & & & Lobsters & 7 & 3 & 3 & 1 & 5 & 2 & 1 & 2 \\
\hline & & & & & Deep sea fish & 4 & 3 & 1 & 0 & 5 & 2 & 3 & 0 \\
\hline \multirow{4}{*}{$\begin{array}{l}\text { Secondary } \\
\text { forest }\end{array}$} & \multirow[t]{4}{*}{ Depletion } & \multirow[t]{4}{*}{7} & \multirow[t]{4}{*}{9} & \multirow[t]{4}{*}{10} & Wild Yam & 23 & 18 & 4 & 0 & 6 & 3 & 3 & 0 \\
\hline & & & & & Land crabs & 22 & 16 & 6 & 0 & 5 & 3 & 2 & 0 \\
\hline & & & & & Coconut crabs & 15 & 13 & 2 & 0 & 3 & 2 & 1 & 0 \\
\hline & & & & & Birds & 11 & 7 & 4 & 0 & 1 & 1 & 0 & 0 \\
\hline \multirow[t]{2}{*}{ Plantations } & \multirow{2}{*}{$\begin{array}{l}\text { Falling market } \\
\text { prices }\end{array}$} & \multirow[t]{2}{*}{1} & \multirow[t]{2}{*}{6} & \multirow[t]{2}{*}{6} & Kava & - & - & - & - & 7 & 2 & 5 & 0 \\
\hline & & & & & Copra & 3 & 0 & 3 & 0 & 3 & 1 & 2 & 0 \\
\hline
\end{tabular}


Thirty-eight out of 44 study participants stated that they are generally satisfied with the yield. Nevertheless, more than half of these $(58 \%, n=22)$, including those dissatisfied with the yields $(n=6)$, would like to increase productivity. Additionally, 13 out of 44 study participants reported that the productivity of their gardens has decreased in recent years mainly due to crop failures. The reasons given for the lack of efforts to increase productivity were lack of time and money and lack of tools, alongside the lack of information regarding cultivation practices and weather (e.g., forecasts).

Plantations of cash crops are more important as income than as a food source. The most widespread plantations in Vanuatu are those with coconut trees for copra production. Occasionally, these coconuts are used to produce cooking oil or for drinking. In some islands, like Gaua, there are silvopastoral systems combining plantations and livestock, or agroforestry systems using coconut trees as shade for other crops, e.g., cacao trees. Copra is by far the most important export commodity of the Banks Islands and is thus a key income source. Recently, however, prices have fallen to such an extent that almost all of the interviewed farmers decided to stop producing copra. Many former copra producers, especially on the island of Gaua, have switched to kava production for which domestic demand has sharply grown.

\subsubsection{Marine resources and secondary forest in livelihood strategies}

In addition to gardens, marine resources are key to local livelihoods (Table 1). Across all communities, various shallow-water reef fish, lobsters, and various molluscs are the most commonly used marine resources, both for private consumption and trade. However, access to marine resources is unequal. Reefs can be either public or owned by tribes. In the second case, tribe leaders grant or deny other community members access to the reef(s). Additionally, the use of deep-sea fish, unlike reef fish, requires a boat and the skill to use it. Although boats can be owned by women or women's organisations, they are almost exclusively operated by men. In addition to access restrictions, interview and workshop participants identified the significant decline in marine resources, especially shallow-water reef fish and various molluscs, as a main livelihood challenge. However, strong variation exists among islands with declines primarily noted on densely populated islands.

Secondary forests are less important as income and food source. The exception within our sample is Mere Lava, where the nut of the Nangai tree is important for the local diet, offering an alternative to protein from fish consumption, which can be constrained by limited reef access. Besides that, study participants on all islands reported that forest products are only occasionally used as a food source. For example, wild yam sometimes serves as a complement to cultivated yam and taro. However, wild yam has an important function as a "famine food" in the case of crop failures. Also, some level of hunting of local species exists, including land crabs, coconut crabs, and different bird species or, on Vanua lava and Gaua, wild cows and boars. As crabs and birds were largely depleted, these species have lost their former importance as a food and income source, especially on Mota Lava. Nevertheless, forests remain an important source for traditional building materials and materials for producing handicraft products, such as baskets or mats, and with that, a significant income source for some of the respondents, especially on Gaua and Mere Lava.

Other sources of income and food are derived from animal husbandry, especially chickens and pigs. Permanent employment was rare and mainly limited to positions in the public sector or in church organisations. Occasional jobs offered within the community are more common, e.g., gardening or construction work. Additionally, younger men are increasingly 
signing up as seasonal workers on plantations and farms abroad. Tourism was mentioned as a further but island-specific source of income. In the Banks, leisure tourism was only developed on the island of Mota Lava and in some communities on Gaua, none of which was part of our sample. Sola also offered accommodation, but this was mainly used in conjunction with the provincial government.

\subsection{Attribution of livelihood challenges to potential causes}

\subsubsection{External causes}

Livelihood challenges, especially those regarding subsistence gardening, were mainly attributed to external causes, with the impacts of climate change to date being the most frequently cited causes. Besides climate change, only wildlife damage on Gaua and volcanic ash from the neighboring island of Ambae on Mere Lava were mentioned as other possible external causes of lower garden productivity. As for climate change, the perception of the severity of the problem differs considerably across islands. During the workshops, the "climate change impacts" on livelihood strategies were reported as more critical than in the interviews (Online Resource 4). We asked the participants to clarify the perceived climate change by describing in detail their observations of changes in weather conditions over a 30-year period and to explain to what extent these changes have affected their livelihood strategies. Study participants reported a total of 90 observations of perceived change in weather conditions (Table 2), 79 of which were described as directly adversely affecting the productivity of gardens or other sources of food and income (Table 3).

The most important negative impact on gardens is, according to local farmers, caused by more frequent extreme weather conditions (Table 3), with long periods of drought and heavy downpours highlighted as weather extremes that occur more frequently than before (Table 2). Regarding dry periods, some respondents referred to the El Niño event in 2015/16. In two other cases, 2018 was described as particularly low in precipitation. Long periods of drought are perceived as a fundamental problem for local gardens. Particularly, farmers reported difficulties with yam, island cabbage, and bananas during dry periods. Moreover, these drought periods were often experienced as being accompanied by high temperatures, conditions associated with increased crop failure, and increased pest outbreaks. Furthermore, high temperatures were seen as a cause of high fish mortality. Except for Merig, people of all islands reported that, especially towards the end of such drought periods, when the water temperature near the shore has risen significantly, it is common to find many dead fish on the beach. In contrast, the impact of heavy rains on crops or natural resources is less severe. Only on Mere Lava did respondents report that heavy rainfall can induce landslides. During severe events, large masses of sand and debris are transported into the sea, which, according to the local population, negatively impacts fish abundance.

Besides extreme events, interviewees and workshops' participants observed changes in weather patterns. In particular, they reported that seasonal weather conditions have become increasingly variable and thus unpredictable (Table 2). For example, fast alternations between sunny dry and wet phases are increasingly occurring during the dry season, which has been described as having been stable and predictable in the past. Respondents reported that the abrupt change between sunshine and rain adversely affects the productivity of gardens by harming large-leaved plants, such as yam or island cabbage, with leaves more susceptible to burns in direct sunlight if they are wet due to previous rain. In addition to these changing patterns, local people also reported a significant intensification of 
Table 2 Perception of climate change. Left side (Observation, Island): Perceived change of weather conditions by study participants of different islands. Right side (Time of occurrence): Month in which the weather conditions were observed. The figures represent the number of mentions in interviews $(N=44$, multiple answers possible). The additional sign $(+)$ indicates cases in which the same weather conditions were mentioned in the course of workshops. Weather records are from the weather station in Sola on Vanua Lava (Department of Meteorology and Geohazards of Vanuatu). MoL, Mota Lava; VL, Vanua Lava; MeL, Mere Lava

\begin{tabular}{|c|c|c|c|c|c|c|c|c|c|c|c|c|c|c|c|c|c|c|}
\hline \multirow[t]{2}{*}{ Observation } & \multicolumn{6}{|c|}{ Island } & \multicolumn{12}{|c|}{ Time of occurrence } \\
\hline & 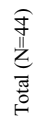 & $\begin{array}{l}\frac{6}{1} \\
z \\
\frac{1}{0} \\
\sum\end{array}$ & 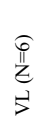 & 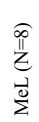 & 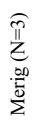 & 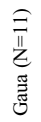 & $\begin{array}{l}\text { 总 } \\
\text { 䔍 }\end{array}$ & 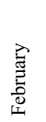 & 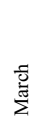 & 豆 & $\stackrel{\overrightarrow{\mathrm{e}}}{\mathrm{d}}$ & 气 & $\stackrel{\lambda}{\Xi}$ & 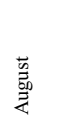 & 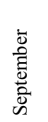 & $\begin{array}{l}\text { गे } \\
\stackrel{0}{0} \\
0 \\
0\end{array}$ & $\begin{array}{l}\dot{J} \\
\text { है } \\
\text { Dे } \\
\text { ठे } \\
\text { z }\end{array}$ & 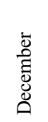 \\
\hline \multicolumn{19}{|c|}{ Weather recordings (average $1990-2019$ ) } \\
\hline Rainfall $[\mathrm{mm}]$ & & & & & & & 384 & 367 & 413 & 425 & 377 & 264 & 236 & 241 & 297 & 366 & 392 & 344 \\
\hline Wind Speed $[\mathrm{m} / \mathrm{s}]$ & & & & & & & 2.9 & 2.4 & 2.2 & 2.1 & 3.3 & 5.3 & 4.9 & 5.3 & 5.1 & 4.3 & 3.4 & 2.8 \\
\hline Temperatures (mean) $\left[\mathrm{C}^{\circ}\right]$ & & & & & & & 27.3 & 27.3 & 27.5 & 27.2 & 26.9 & 26.4 & 26.0 & 25.8 & 25.9 & 26.2 & 26.7 & 27.3 \\
\hline Perceived Change (unspecific) & 41 & 13 & 6 & 8 & 3 & 11 & & & & & & & & & & & & \\
\hline Changes in weather pattern & 53 & 9 & 8 & 15 & 5 & 16 & & & & & & & & & & & & \\
\hline Seasonal atypical weather cond. & 15 & 5 & 3 & $1^{+}$ & 2 & $4^{+}$ & & & & & & 2 & 2 & 2 & 2 & 2 & 1 & 1 \\
\hline On average more precipitation & 14 & 1 & $1^{+}$ & $8^{+}$ & 1 & $3^{+}$ & $1^{+}$ & $1^{+}$ & $7^{+}$ & $6^{+}$ & 5 & & & & + & $2^{+}$ & $3^{+}$ & $3^{+}$ \\
\hline Stronger winds & 9 & 1 & & $4^{+}$ & 1 & $3^{+}$ & 1 & 1 & 3 & 3 & $1^{+}$ & 1 & 1 & 1 & $1^{+}$ & 1 & 2 & 1 \\
\hline Fast changing weather cond. & 8 & 1 & 3 & 1 & & 3 & & & & & 1 & 1 & 1 & & & & & \\
\hline On average less precipitation & 5 & 1 & 1 & 1 & 1 & 1 & & & & & & & & & & & & \\
\hline Increasing temperature & 2 & & & & & 2 & & & & & 1 & 1 & 1 & 1 & 1 & & & \\
\hline Weather extremes & 28 & 8 & 4 & 3 & 3 & 10 & & & & & & & & & & & & \\
\hline More frequent droughts & 12 & $4^{+}$ & 2 & 1 & 3 & $2^{+}$ & + & + & & & & 1 & 1 & 1 & & & & \\
\hline More heavy downpours & 11 & 4 & $1^{+}$ & $2^{+}$ & & $4^{+}$ & + & + & + & + & & + & + & & + & + & ++ & + \\
\hline More often very hot and sunny & 5 & & 1 & & & 4 & & & & & & & & & & & & \\
\hline Shift of seasons & 9 & 5 & 2 & 1 & 1 & & & & & & & & & & & & & \\
\hline Early rain season & 3 & 3 & & & & & & & & & & & & & & & & \\
\hline Unspecific change & 2 & 1 & 1 & & & & & & & & & & & & & & & \\
\hline Earlier dry season & 2 & & & $1^{+}$ & 1 & & & & & & & & & & & & & \\
\hline Shorter wet season & 1 & 1 & & & & & & & & & & & & & & & & \\
\hline Cyclone outside season & 1 & & 1 & & & & & & & & & & & & & & & \\
\hline Total specific observations & 90 & 22 & 14 & 19 & 9 & 26 & & & & & & & & & & & & \\
\hline
\end{tabular}

Table 3 Local perceptions of how climate change is affecting vital food and income sources. The figures represent the number of mentions in interviews $(N=44$, multiple answers possible). The additional sign $(+)$ indicates cases in which the same impact was mentioned in the course of a workshop

\begin{tabular}{|c|c|c|c|c|c|c|c|c|c|c|c|}
\hline \multirow[t]{2}{*}{ Observation } & \multicolumn{5}{|c|}{ Gardens } & \multirow[b]{2}{*}{$\begin{array}{l}\dot{u} \\
\vec{\Xi} \\
\frac{a}{a}\end{array}$} & \multirow[b]{2}{*}{ 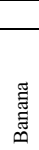 } & \multirow[b]{2}{*}{ 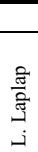 } & \multirow[b]{2}{*}{$\underset{巳}{\stackrel{\Xi}{\Xi}}$} & \multicolumn{2}{|c|}{ Forests Sea } \\
\hline & 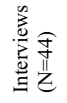 & $\begin{array}{l}\bar{\Xi} \\
\stackrel{0}{0}\end{array}$ & 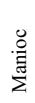 & $\underset{\beth}{\Xi}$ & 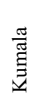 & & & & & & \\
\hline Climate Change (no specific.) & 20 & $7^{++++}$ & 1 & 1 & & 2 & & 1 & 2 & $3^{++++}$ & $3^{++++}$ \\
\hline Changes in weather pattern & 39 & 6 & 3 & 8 & 3 & 8 & 2 & 1 & 1 & & 7 \\
\hline Seasonal atypical weather cond. & 4 & 1 & 1 & & & 1 & 1 & & & & \\
\hline On average more precipitation & 10 & 1 & & $5^{+++}$ & 3 & 1 & & & & & \\
\hline Stronger winds & 14 & 3 & $2^{+}$ & & & 1 & $1^{+}$ & & 1 & & $6^{++++}$ \\
\hline Fast changing weather cond. & 7 & & & 3 & & $3^{++}$ & & 1 & & & \\
\hline On average less precipitation & 3 & 1 & & & & 2 & & & & & \\
\hline Increasing temperature & 1 & & & & & & & & & & $1^{+}$ \\
\hline Weather extremes & 35 & 6 & 1 & 9 & 2 & 8 & 4 & 2 & & 1 & 2 \\
\hline Droughts ${ }^{l}$ & 17 & 3 & & 5 & 1 & 5 & 3 & & & & \\
\hline Heavy downpours & 11 & 3 & $1^{+}$ & 2 & $1^{+}$ & 1 & 1 & & & $1^{+}$ & 1 \\
\hline Hot/Sunny & 7 & & & 2 & & 2 & & 2 & & & $1^{+}$ \\
\hline Shift of seasons & 5 & 3 & & & & 1 & & & 1 & & \\
\hline Early rain season & 2 & 1 & & & & 1 & & & & & \\
\hline Earlier dry season & 1 & & & & & & & & 1 & & \\
\hline Shorter wet season & 2 & 2 & & & & & & & & & \\
\hline Total specific observations & 79 & 15 & 4 & 17 & 5 & 17 & 6 & 3 & 2 & 1 & 9 \\
\hline
\end{tabular}


prevailing weather conditions, especially during the rainy season, when more rain falls than before, especially prior to the transition towards the dry season. Farmers reported that more precipitation throughout the year affects tuber plants, such as yam (Table 3). Local farmers considered that these plants are particularly susceptible to moisture conditions during the growth phase when the tubers are still immature. Besides, people reported new wind regimes in which both wind strength and direction have changed to adversely affect the productivity of gardens. Strong winds cause shoots to break and transport sea salt to gardens, which is believed to negatively influence the health of crops. Changes in the wind also affect the coasts and the sea. On all islands studied, people observed increasing coastal erosion, which they saw as caused by high swell. Whereas coastal erosion is not perceived as a threat to food security or income, high swells can hinder or even impede fishing.

While the attribution of perceived livelihood challenges to extreme weather events was relatively consistent in the interviews and during the workshops, study participants expressed greater uncertainty and doubts in explaining the impact of gradual changes in climatic conditions (e.g., shift of seasons). Additionally, the effects of gradual change were framed much more broadly, for example, as being generally responsible for declining productivity of gardens and ecosystems, but without providing further reasoning (Table 3). Moreover, while study participants had less difficulty specifying how climate change has impacted gardens to date, they had difficulty describing impacts on secondary forests or on marine resources.

Observations of study participants partially overlap with trends shown by records from the only available weather station in Sola, on Vanua Lava, e.g., regarding both increasing average temperature and more frequent periods of heat. However, more divergence exists than convergence between observations and weather records (Online Resource 5). For instance, although an increase in mean annual precipitation is discernible in weather recordings and has also been observed by some study participants, the observation of higher precipitation during the transition between southern summer and winter (April-May) is not supported by weather recordings. Furthermore, study participants observed that droughts occur more frequently today than they did in the past and last longer. This observation, again, is not discernible in the weather recordings.

\subsubsection{Internal causes}

Through a structured discussion, the participants in the workshops concluded that, besides external causes, some management practices may also partially explain the reduction in the productivity of agroecosystems. To facilitate the discussion, any changes in management practices were considered as "internal causes" (within the sphere of influence of the community).

Regarding marine resources and secondary forest, interview and workshop participants concluded that unsustainable management of natural resources, i.e., over-exploitation and/or the use of more efficient techniques, is likeliest to have declined the natural resources that are key to livelihoods, as illustrated by the following quotation.

Before, birds were hunted with bow and arrow. This was a difficult task. Nowadays, a lot of people hunt with slingshots, which is a highly effective method. (\#30, Mere Lava, face-to-face interviews, translated from Bislama) 
Inadequate garden management was mentioned only four times as a possible cause of the challenges during the interviews. In these four cases, new and potentially inadequate practices were either interpreted as a collective failure (we forgot the traditional way of gardening) or as someone else's problem, such as in the following quotation.

Young people forgot the traditional calendar. This is why young people face problems with their gardens [...] (\#18, Vanua Lava, face-to-face interviews, translated from Bislama)

During the workshops, the focus shifted from external to internal causal attribution. Participants increasingly discussed the possibility that, besides climate change, inadequate practices may also be relevant for poor garden performance. Overall, three gardening practices were identified as a possible factor in the decrease in productivity due to incorrect application: shifting cultivation, crop rotation, and changes in the planting schedule.

Regarding shifting cultivation, the length of time that a field is cultivated no longer corresponds to traditional practices. On Gaua and Mota Lava, participants concluded that the fallow period is considerably shorter today and in some cases, there is no more shifting cultivation at all. Longer cultivation periods are seen as a possible cause of poor soil, necessitating reduced productivity. This development was, according to workshop participants, driven by high population density and thus land scarcity. According to local agricultural experts, the considerable effort involved in relocating cultivation, particularly in the early stages of deforestation, could also be a factor fostering changes in shifting cultivation. Some growers cannot or do not want to invest such effort anymore, partly because gardens are increasingly competing with other livelihood strategies that require less effort or promise higher yields, such as tourism or deep-sea fishing. In contrast, the discussions during the workshops and visits to the gardens revealed that shifting cultivation is still practiced on the more remote islands of Mere Lava and Merig, and that the applied fallow period of 5 to 7 years still corresponds with the traditional practices of the Banks.

Crop rotation was also mentioned as having changed significantly. On Mota Lava and partially in Gaua, visits to gardens revealed that various crops are planted simultaneously and in a combination that does not correspond to traditional crop rotation schemes. In contrast, traditional crop rotation techniques are still practiced on the more remote islands of Mere Lava and Merig. On these islands, yam, taro, or manioc is planted first, followed by other crops, such as island cabbage, banana, pineapple (on Mere Lava), or different kinds of vegetables.

The third potentially inadequate practice stated as a possible cause of lower productivity was unsuitable timing of planting. On Mota Lava, a lively discussion in the vernacular language of the island about the question of how heavy rainfall affects young tuber plants was summarized by one participant with the following statement:

We cannot answer this question because everyone is planting at a different moment in time and therefore is affected to a different degree [by the same event]. (Mota Lava, workshop)

Inconsistent practices regarding the timing of planting appear in almost all islands (Table 4). For example, both traditional calendars and local authorities recommend that manioc be planted from June to October to ensure that each growing phase of the plant can occur under the most favorable climatic conditions, i.e., planting from May to July. Despite these recommendations, farmers on all islands, except Vanua Lava, plant manioc 
throughout the year (Table 4). Non-adherence to planting calendars was observed for all main crops (Table 4). Some farmers reasoned that traditional calendars were increasingly losing their validity due to changing climatic conditions. Other farmers were well aware that they were planting outside the recommended seasons and expected reduced production outside the recommended seasons. They did this to meet the constant demand of local markets for some garden products. Another reason for abandoning traditional calendars is that people simply forget them. Lack of knowledge was also mentioned as one reason for not implementing the recommendations of the authorities.

\section{Discussion}

Local knowledge of communities in North Vanuatu enables assessment of climatic conditions and changes at a level of granularity far beyond the one achievable with the available weather data for the region. The records from Sola on Vanua Lava, the only weather station in the region, reflect specific orographic weather conditions that may significantly differ from the conditions on other islands due to different topographies (Smith et al. 2012; Wotling et al. 2000). For example, while orographic precipitation or cloud cover is typical for larger islands with high terrain, such as Vanua Lava, Gaua, and Mere Lava, these phenomena do not occur on small and flat islands, such as Merig (Yang and Chen 2008). This may explain why the residents of Merig increasingly face dry conditions during winter months, whereas this is not a pressing issue on the $20-\mathrm{km}$ distant Gaua or the $30-\mathrm{km}$ distant Mere Lava. This may also explain why the weather station in Sola has not recorded a clear trend in this respect. Vegetation and geographical location are also important factors that influence local microclimates. For example, locations on windward coasts (southeast) are more exposed to rain and salt spray than locations on leeward coasts (northwest) (Smith et al. 2012). In our study, only the participants from the community of Aota, which is located on the southeast coast of Mere Lava, reported increasing problematic salt input from the sea into their gardens due to strong winds. Besides the exposure, the impact of a particular event also depends on the vulnerability of an individual's livelihood strategies

Table 4 Planting schedule for different crops on the different islands. Red framed are the periods recommended by Vanuatu's Department of Agriculture. Gray fields indicate the range of times where the respective crops are actually planted ( source: workshops and interviews)

\begin{tabular}{|c|c|c|c|c|c|c|c|c|c|c|c|c|c|}
\hline Crop & Island & 馬 & $\dot{0}$ & 嵌 & 岁 & $\stackrel{\overrightarrow{\mathrm{I}}}{\mathrm{d}}$ & 宓 & $\dot{\Xi}$ & $\stackrel{\text { Di }}{z}$ & 芯 & $\ddot{0}$ & 官 & ه̊ \\
\hline Yam & $\begin{array}{l}\text { Mota Lava } \\
\text { Vanua Lava } \\
\text { Mere Lava } \\
\text { Merig } \\
\text { Gaua }\end{array}$ & & & & & & & & & & & & \\
\hline Kumala & $\begin{array}{l}\text { Mota Lava } \\
\text { Vanua Lava } \\
\text { Mere Lava } \\
\text { Merig } \\
\text { Gaua }\end{array}$ & & & & & & & & & & & & \\
\hline $\begin{array}{l}\text { Island } \\
\text { Cabbage }\end{array}$ & $\begin{array}{l}\text { Merig } \\
\text { All other islands }\end{array}$ & & & & & & & & & & & & \\
\hline Manioc & $\begin{array}{l}\text { Vanua Lava } \\
\text { All other islands }\end{array}$ & & & & & & & & & & & & \\
\hline Banana & All islands & & & & & & & & & & & & \\
\hline
\end{tabular}


and how these are pursued (Osbahr et al. 2011). For example, in our case study, severity of the droughts' impact on production may depend on the crop varieties planted and/or the time of planting.

Local communities consider climate change as the main cause of several challenges they face in pursuing their livelihood strategies. Especially the increased occurrence of droughts, on average more precipitation, and seasonal atypical weather conditions are observed as having detrimental impacts on the productivity of gardens. Extreme events have always been part of life in North Vanuatu; thus, there is traditional local knowledge related to these phenomena, their impacts, and the corresponding coping strategies. This might explain why the attribution of livelihood vulnerability (change) to an (increasing) extreme event was consistent across interviews and during the workshops. In contrast, the attribution of livelihood vulnerability to gradual changes in climatic conditions was not as clear. This finding highlights the need to increase the knowledge about how gradual changes in climatic conditions affect livelihood vulnerabilities and if/how these impacts are connected to specificities of the livelihood strategy (e.g., planting schemes for a given crop).

During a participatory analysis of the results in the workshops, the participants increasingly considered internal rather than external factors (e.g., climate change) as the causes of vulnerabilities. Particularly, the workshop participants identified unsustainable and inadequate resource and gardening management practices as responsible for compromising the effectiveness of local livelihood strategies in many cases. Although many local actors perceive unsustainable management as the main cause of challenges regarding the availability of natural resources as sources of food and income, our data do not allow such weighting regarding the cause leading to lower productivity in gardens. Climate change and unsustainable management practices can independently cause a decline in productivity. However, they can also be (and probably are more often) intertwined with each other and with other causes of vulnerability. For example, while unsuitable management practices can directly lead to a decline in productivity, they can also act as catalysts for vulnerability, potentially exacerbating the impacts of climate change. For instance, incorrect timing of planting results in different stages of growth during seasons with unfavorable climatic conditions, which in turn potentially increase the stress level of crops, thereby negatively affecting their productivity or even inducing a partial loss of the harvest. These effects can unfold independently of climate change. However, increased stress levels can also decrease the resilience of plants, increasing their likelihood of having difficulty in withstanding climatic anomalies (Dhankher and Foyer 2018).

The observed shift in attribution from external to internal causes suggests that not the entire local knowledge was activated in the initial attribution of causes of livelihood vulnerabilities. Only through participatory reflection did all the knowledge available in the community flow into the analysis and allow a more nuanced attribution. This shows that an initial local attribution may not reflect all local knowledge and as a result may overstate or understate a cause, such as climate change. This raises the question of why parts of local knowledge have not been included in the attribution from the beginning. To answer this question, it is worth taking a more nuanced look at local knowledge.

We find two types of local knowledge relevant for local attribution of livelihood vulnerabilities to possible causes: traditional knowledge acquired over a long period by a community and "new" or contemporary knowledge acquired continuously by an individual or a part of a community. Local attribution should thus be understood as a dynamic process that is constantly reexamined, reshaped, and supplemented, both collectively and individually. This view of local attribution has strong similarities with Groeben and Scheele's 
(2020) concept of subjective theory, which states that individuals use their personal experiences and accumulated knowledge to explain the experienced world through theories of an "if-then" relation. This concept also understands subjective knowledge about the world, which develops and thus constantly changes in the course of a life biography, as the basis of subjective theories.

With this in mind, we conclude that ambiguity in attribution is more likely when local attribution relies mainly on contemporary knowledge. This type of knowledge is less consolidated than traditional knowledge because it is more subject to change and is constantly being supplemented by new knowledge. While this allows emerging or new phenomena to be included in attribution, it also entails constant renegotiation to clarify which knowledge component is better suited for explaining a particular phenomenon. In contrast, causal relations that can be explained with traditional knowledge (e.g., impacts of droughts on particular crops) seem to be more solidified and can be retrieved more immediately. We identify two main factors that may influence the use of each type of knowledge and thus become critical to how locals assign livelihood vulnerability to causes: influence of prevailing narratives on individual perceptions of study participants and social desirability.

Numerous awareness initiatives by government agencies and NGOs have made "climate change" a well-known concept throughout the country (National Advisory Board on Climate Change \& Disaster Risk Reduction [NAB] 2020; Yaro 2013), thereby establishing narratives about the high vulnerability of Vanuatu's society, environment, and economy to climate change. Consistent with these narratives, locals initially tended to identify climate change as an explicit cause of threats to their livelihoods, particularly threats to agroforestry gardens. To what extent have these established narratives influenced the local knowledge of those affected and thus local attribution? It is well documented that narratives can influence attitudes and perceptions, which is why they have increasingly been used purposefully to communicate scientific content to non-experts (Dahlstrom and Rosenthal 2018). However, how audiences (in our case the people of North Vanuatu) process this information also largely depends on how it aligns with their own perspectives and values (Kahan 2012). As an indication of this phenomenon in Vanuatu, some responses suggested that climate change concepts and terms were sometimes used but without any contextualization. Thus, study participants used terms such as "global warming" or "sea-level rise" but could not apply these to specific everyday situations. For example, a participant reported that the rise in sea level, due to the melting of the Arctic pack ice, may risk local livelihoods but could not explain how. Moreover, in informal discussions after the interviews, some participants added that they had heard from others that lower productivity was due to climate change, but they were unsure if this was true. The mixture of hearing (non-contextualized) information and the participants' own observations seems to be particularly prevalent regarding the impacts of long-term incremental changes, such as a continuous rise in temperature or sea level. A plausible explanation is that some statements about climate change and its implications for local livelihoods contain elements of external climate narratives and are not based on or validated by actual observations. A similar influence has also been suggested by other authors who have examined local populations' perceptions of climate change (Mertz et al. 2009; Tschakert 2007).

It is difficult to determine whether these narratives were adopted in part because they corresponded to the participants' observations and experiences or were consistent with their own values. While either case is or both are certainly possible, given the study participants' detailed descriptions of climate change and its impacts, peer influence could be another plausible explanation. Prevailing narratives may have induced a social desirability 
bias, where the participants tend to respond in a way that supposedly follows the views of other participants or persons perceived as knowledgeable (e.g., scientists, politicians, or representatives from the national government) (Grimm 2010; Roxas and Lindsay 2012). Opposing the views of the group or the experts can be difficult (Kahan 2012). A social desirability bias could explain why in this study the local community members described climate change as more problematic during the workshops than during the interviews (Online Resource 4).

Social desirability as a potential confounder of responses has received much attention in the social sciences, particularly in behavioral research (e.g., environmental behavior), when people self-report their actions or attitudes (Fisher 1993; Palutikof et al. 2004; Vesely and Klöckner 2020). Although the concept has gained some attention in research on behavior related to and attitudes toward climate change (Bord et al. 1998), studies that investigate local knowledge and perceptions about the impacts of climate change on livelihood strategies have not given much consideration to social desirability. To our knowledge, Tessema et al.'s (2019) study is the only one that has examined their participant interviews in terms of a possible social desirability bias. They have found that this could be a plausible reason why local farmers initially labeled changes in cropping techniques as agricultural adaptation strategies to climate change before framing the changes as the result of market-based stimuli (Tessema et al., 2019). We consider the influences of dominant narratives on both individual perceptions and social desirability to be plausible reasons for the observed shift from external to internal causal attribution. However, this needs to be confirmed by future research.

Various techniques have been suggested to overcome the social desirability bias, for example, indirect questioning (Fisher and Tellis 1998). We believe that the combination of methods we employed, as well as the conceptual framing based on Jahn and colleagues' (2012) transdisciplinary model, is a well-suited approach for contexts with similar linguistic and cultural realities, as in Vanuatu, to uncover norms and underlying narratives (Börger 2012; Grimm 2010) and thus identify a possible social desirability bias. This is important because local knowledge is increasingly assigned a central role in vulnerability assessment. Therefore, if such bias is not recognized, the narratives risk being reified, with potential new insights being overlooked.

Our study illustrates the importance of nuanced incorporation of local knowledge into livelihood vulnerability assessments. Using traditional and contemporary local knowledge in the analysis allows differentiation of the potential impacts of multiple drivers, including climate change, integration of new management practices, or changing consumption patterns. Such an analysis certainly increases the appropriateness of adaptation policies and measures for the context realities. Our discussion on the influence of prevailing narratives does not undermine the legitimacy or the value of local knowledge. Rather, we emphasize the need to mobilize traditional and contemporary local knowledge for local attribution and its validation through participatory and transdisciplinary methods. This is also a call for practitioners and scholars to contextualize climate change-related knowledge before/when sharing it with local communities.

Supplementary Information The online version contains supplementary material available at https://doi. org/10.1007/s10584-021-03221-x.

Acknowledgements We are indebted to the members of the communities who shared their time, expertise, and knowledge with us. We also wish to warmly thank Prof. Michael Stauffacher from ETH Zurich, Dr. Krishna Kumar Kotra from the University of the South Pacific, and Henline Mala from the Vanuatu Cultural Center for providing help and guidance throughout the study. We are grateful to John and Solomon Dini for 
their valuable assistance in the communities. We are also grateful to ETH Zurich for funding this research. Finally, thank you to the reviewers for their helpful and constructive comments and suggestions.

Funding Open Access funding provided by ETH Zurich.

Open Access This article is licensed under a Creative Commons Attribution 4.0 International License, which permits use, sharing, adaptation, distribution and reproduction in any medium or format, as long as you give appropriate credit to the original author(s) and the source, provide a link to the Creative Commons licence, and indicate if changes were made. The images or other third party material in this article are included in the article's Creative Commons licence, unless indicated otherwise in a credit line to the material. If material is not included in the article's Creative Commons licence and your intended use is not permitted by statutory regulation or exceeds the permitted use, you will need to obtain permission directly from the copyright holder. To view a copy of this licence, visit http://creativecommons.org/licenses/by/4.0/.

\section{References}

Allen M (2017) The sage encyclopedia of communication research methods (1-4). SAGE Publications, Thousand Oaks. https://doi.org/10.4135/9781483381411

Allen B, Bourke M (2009) People, land and environment. In: Bourke MR, Harwood T (eds) Food and agriculture in Papua New Guinea. Australian National University E Press, Canberra, pp 27-127

Ayanlade A, Radeny M, Morton JF (2017) Comparing smallholder farmers' perception of climate change with meteorological data: a case study from southwestern Nigeria. Weather Clim Extremes 15:24-33

Blair A, Momtaz S (2019) Climate variability and change in the Caribbean and the south pacific learning from farmers perceptions and responses in Antigua and Efate. Curr Trends in Oceanogr Mar Sci 109(2). https://doi.org/10.29011/CTOMS-109.100009

Bord RJ, Fischer A, O'Connor RE (1998) Public perceptions of global warming: United States and international perspectives. Clim Res 11:75-84

Böhm A (2012) Theoretisches Codieren: Textanalyse in der Grounded Theory In: Flick U, von Kardorff E, Steinke I (ed) Qualitative Forschung. Ein Handbuch. Reinbek bei Hamburg: Rowohlt Taschenbuch Verlag. pp. $477-478$

Börger T (2012) Social desirability and environmental valuation. Hohenheimer Volkswirtschaftliche Schriften Band 66. Peter Land International Academic Publishers, Frankfurt a.M. p 5. https://doi.org/10. 3726/978-3-653-01583-6

Chambers R (2006) Participatory mapping and geographic information systems: whose map? Who is empowered and who disempowered? Who gains and who loses? Electron J Inf Syst Dev Ctries 25(1)

Cillaurren E, David G (2001) Grandperrin R (2001) Coastal fisheries atlas of Vanuatu: a 10-year development assessment. IRD, Paris

Connell J (2015) Food security in the island Pacific: is Micronesia as far away as ever? Reg Environ Chang 15(7):1299-1311. https://doi.org/10.1007/s10113-014-0696-7

Creswell JW, Miller DL (2000) Determining validity in qualitative inquiry. Theory Pract 39(3):124-130

Dahlstrom MF, Rosenthal S (2018) Third-person perception of science narratives: the case of climate change denial. Sci Commun 40(3):340-365

Dhankher OP, Foyer CH (2018) Climate resilient crops for improving global food security and safety. Plant Cell Environ 41(5):877-884. https://doi.org/10.1111/pce.13207

Department of Agriculture and Rural Development [DARD], Government of Vanuatu (2017) Agricultural Industries. http://www.malffb.gov.vu/index.php?id=1. Accessed 20 Sept 2020

Dorward P, Osbahr H, Sutcliffe C, Mbeche R (2020) Supporting climate change adaptation using historical climate analysis. Clim Dev 12(5):469-480. https://doi.org/10.1080/17565529.2019.1642177

FAO (2010) Building resilience to climate change: root crop and fishery production. Pacific Food Security Toolkit. Food and Agriculture Organisation of the United Nations, Rome. http://www.fao.org/3/ am014e/am014e.pdf. Accessed 20 Sept 2020

FAO (2016) Climate change and food security: risks and responses. Food and Agriculture Organisation of the United Nations, Rome. http://www.fao.org/3/a-i5188e.pdf. Accessed: 20 Sept 2020

Fazey I, Kesby M, Evely A et al (2010) A three-tiered approach to participatory vulnerability assessment in the Solomon Islands. Glob Environ Chang 20(4):713-728 
Feeny S, McDonald L, Miller-Dawkins M (2013) Household vulnerability and resilience to shocks: findings from Solomon Islands and Vanuatu. SSGM Discussion Paper 2013/2. https://core.ac.uk/download/pdf/ 156621881.pdf. Accessed 22 Sept 2020

Fisher RJ (1993) Social desirability bias and the validity of indirect questioning. J Consum Res 20(2):303-315

Fisher RJ, Tellis GJ (1998) Removing social desirability bias with indirect questioning: is the cure worse than the disease? N Am Advances Consume Res 25

Granderson AA (2017) The role of traditional knowledge in building adaptive capacity for climate change: perspectives from Vanuatu. Weather Clim Soc 9(3):545-561

Grimm P (2010) Social desirability bias. In: Sheth J, Malhotra N (ed) Wiley international encyclopedia of marketing. https://doi.org/10.1002/9781444316568.wiem02057

Groeben N, Scheele B (2020) Forschungsprogramm subjektive theorien. In: Mey G, Mruck K (eds) Handbuch Qualitative Forschung in der Psychologie. Springer, Wiesbaden. https://doi.org/10.1007/978-3658-18234-2_10

Goodman LA (1961) Snowball sampling. Ann Math. Stat 31(1):148-170

Guillaumont P (2010) Assessing the economic vulnerability of small island developing states and the least developed countries. J Dev Stud 46(5):828-854

Howe PD, Markowitz EM, Lee TM et al (2013) Global perceptions of local temperature change. Nat Clim Chang 3(4):352-356. https://doi.org/10.1038/Nclimate1768

IPCC (2012) Managing the risks of extreme events and disasters to advance climate change adaptation. In: Field CB, Barros VR, Stocker TF et al (eds) A Special Report of Working Groups I and II of the Intergovernmental Panel on Climate Change. Cambridge University Press, Cambridge, p 582

IPCC (2014a) Climate Change 2014: impacts, adaptation, and vulnerability. Part A: Global and Sectoral Aspects. In: Field CB, Barros VR, Dokken DJ et al (eds) Contribution of Working Group II to the Fifth Assessment Report of the Intergovernmental Panel on Climate Change. Cambridge University Press, Cambridge, p 1132

IPCC (2014b) Climate Change 2014: impacts, adaptation, and vulnerability. Part B: Regional Aspects. In: Barros VR, Field CB, Dokken DJ et al (eds) Contribution of Working Group II to the Fifth Assessment Report of the Intergovernmental Panel on Climate Change. Cambridge University Press, Cambridge, p 688

Jahn T, Bergmann M, Keil F (2012) Transdisciplinarity: between mainstreaming and marginalization. Ecol Econ 79:1-10. https://doi.org/10.1016/j.ecolecon.2012.04.017

Kahan D (2012) Why we are poles apart on climate change. Nat News 488(7411):255

Lefale PF (2010) Ua'afa le Aso Stormy weather today: traditional ecological knowledge of weather and climate. The Samoa experiencce. Clim Chang 100(2):317-335

Lowitt K, Ville AS, Lewis P, Hickey GM (2015) Environmental change and food security: the special case of small island developing states. Reg Environ Chang 15(7):1293-1298. https://doi.org/10.1007/ s10113-015-0849-3

Mayring P (2002) Qualitative Sozialforschung, vol 5. Belz Verlag, Weinheim

McGregor A, Bourke RM, Manley M, Tubuna S, Deo R (2009) Pacific island food security: situation, challenges and opportunities. Pac Econ Bull 24(2):24-42

McNamara K, McNamara J (2011) Using participatory action research to share knowledge of the local environment and climate change: case study of Erub Island, Torres Strait. Aust J Indig Educ 40:30-39. https://doi.org/10.1375/ajie.40.30

McNamara KE, Prasad SS (2014) Coping with extreme weather: communities in Fiji and Vanuatu share their experiences and knowledge. Clim Chang 123(2):121-132. https://doi.org/10.1007/s10584-013-1047-2

Mercer J, Kelman I, Taranis L, Suchet-Pearson S (2010) Framework for integrating indigenous and scientific knowledge for disaster risk reduction. Disasters 34(1):214-239. https://doi.org/10.1111/j.14677717.2009.01126.x

Mertz O, Mbow C, Reenberg A, Diouf A (2009) Farmers' perceptions of climate change and agricultural adaptation strategies in rural Sahel. Environ Manag 43(5):804-816. https://doi.org/10.1007/ s00267-008-9197-0

Mondragon C (2018) Forest, reef and seal-level rise in North Vanuatu: seasonal environmental practices and climate fluctuations in Island Melanesia. In: Nakashima D, Krupnik I, Rubis JT (eds) Indigenous knowledge for climate change assessment and adaptation. Local \& Indigenous Knowledge 2. Cambridge University Press and UNESCO, Cambridge

National Advisory Board on Climate Change \& Disaster Risk Reduction [NAB], Government of Vanuatu (2020) Climate change initiatives and activities in Vanuatu. https://www.nab.vu/climate-change-initi atives-and-activities-vanuatu. Accessed 20 Sept 2020 
National Advisory Committee on Climate Change, Government of Vanuatu [NACCC] (2007) National Adaptation Programme for Action (NAPA). 56. http://unfccc.int/resource/docs/napa/vut01.pdf. Accessed 20 Sept 2020

Osbahr H, Dorward P, Stern R, Cooper S (2011) Supporting agricultural innovation in Uganda to respond to climate risk: linking climate change and variability with farmer perceptions. Exp Agric 47(2):293-316

Palutikof JP, Agnew MD, Hoar MR (2004) Public perceptions of unusually warm weather in the UK: impacts, responses and adaptations. Clim Res 26(1):43-59

Pohl C, Krütli P, Stauffacher M (2017) Ten reflective steps for rendering research societally relevant. GAIA-Ecol Perspect Sci Soc 26(1):43-51. https://doi.org/10.14512/gaia.26.1.10

Rao KPC, Ndegwa WG, Kizito K, Oyoo A (2011) Climate variability and change: farmer perceptions and understanding of intra-seasonal variability in rainfall and associated risk in semi-arid Kenya. Exp Agric 47(2):267-291. https://doi.org/10.1017/S0014479710000918

Reyes-Garcia V, Fernandez-Llamazares A, Gueze M et al (2016) Local indicators of climate change: the potential contribution of local knowledge to climate research. Wiley Interdiscip Rev Clim Chang 7(1):109-124. https://doi.org/10.1002/wcc.374

Ribot J (2010) Vulnerability does not just fall from the sky: toward multi-scale pro-poor climate policy. In: Mearns R, Norton A (eds) Social dimensions of climate change: equity and vulnerability in a warming world. The World Bank, Washington

Ribot J (2014) Cause and response: vulnerability and climate in the Anthropocene. J Peasant Stud 41(5):667-705

Ritchie J, Spencer L, O’Connor W (2003) Carrying out Qualitative Analysis In: Ritchie J, Lewis J (ed) Qualitative Research Practice: A Guide for Social Science Students and Researchers. London UK: SAGE Publications. pp. 220-248

Roulston K (2010) Reflective interviewing: a guide to theory and practice. SAGE Publications, Thousand Oaks, p 86. https://doi.org/10.4135/9781446288009

Roxas B, Lindsay V (2012) Social desirability bias in survey research on sustainable development in small firms: an exploratory analysis of survey mode effect. Bus Strategy Environ 21(4):223-235. https://doi.org/10.1002/bse.730

Setten G, Lein H (2019) "We draw on what we know anyway": the meaning and role of local knowledge in natural hazard management. Int j Disaster Risk Reduct 38:101184. https://doi.org/10.1016/j.ijdrr. 2019.101184

Smith RB, Minder JR, Nugent AD et al (2012) Orographic precipitation in the tropics: the Dominica Experiment. Bull Am Meteorol Soc 93(10):1567. https://doi.org/10.1175/Bams-D-11-00194.1

Swim J, Clayton S, Doherty T et al (2009) Psychology and global climate change: addressing a multifaceted phenomenon and set of challenges. A report by the American Psychological Association's task force on the interface between psychology and global climate change. American Psychological Association, Washington. https://www.apa.org/science/about/publications/climate-change. Access 20 Sept 2020

Tessema YA, Joerin J, Patt A (2019) Climate change as a motivating factor for farm-adjustments: rethinking the link. Clim Risk Manag 23:136-145

Tschakert P (2007) Views from the vulnerable: understanding climatic and other stressors in the Sahel. Glob Environ Change 17(3-4):381-396

Vanuatu National Statistics Office [VNSO], Ministry of Finance and Economic Management, Government of Vanuatu (2009) National Population and Housing Census. Port Vila, Vanuatu. https://vnso. gov.vu/index.php/census-and-surveys/census/2009-census. Access 20 Sept 2020

Vanuatu National Statistics Office [VNSO], Ministry of Finance and Economic Management, Government of Vanuatu (2012) Household Income and Expenditure Survey 2010. Port Vila, Vanuatu. https://mjcs.gov.vu/images/research_database/2010_HIES_REPORT.pdf. Access 20 Sept 2020

Vesely S, Klöckner CA (2020) Social desirability in environmental psychology research: three metaanalyses. Front Psychol 11.

Walker J, Mitchell B, Wismer S (2001) Livelihood strategy approach to community- based planning and assessment: a case study of Molas, Indonesia. Impact Assess Proj Appraisal 19(4):297-309. https:// doi.org/10.3152/147154601781766925

Warrick O (2011) The adaptive capacity of the Tegua island community, Torres Islands, Vanuatu. Australian Government: Department of Climate Change and Energy Efficiency. https://www.envir onment.gov.au/system/files/resources/26e3a6ec-d45e-4c95-8cda-fecfe9ae981c/files/usp-adaptivecapacity-vanuatu.pdf. Access 07 Apr 2021

World Food Programme (2004) Vulnerability analysis and mapping: a tentative methodology. https:// de.scribd.com/document/6702052/Vulnerabiltiy-Analysis-and-Mapping-Wfp. Access 25 Sept 2020 
Wotling G, Bouvier C, Danloux J, Fritsch JM (2000) Regionalization of extreme precipitation distribution using the principal components of the topographical environment. J Hydrol 233(1-4):86-101. https://doi.org/10.1016/S0022-1694(00)00232-8

Yang Y, Chen YL (2008) Effects of terrain heights and sizes on island-scale circulations and rainfall for the island of Hawaii during HaRP. Mon Weather Rev 136(1):120-146. https://doi.org/10.1175/2007m wr1984.1

Yaro JA (2013) The perception of and adaptation to climate variability/change in Ghana by smallscale and commercial farmers. Reg Environ Chang 13(6):1259-1272. https://doi.org/10.1007/ s10113-013-0443-5

Publisher's note Springer Nature remains neutral with regard to jurisdictional claims in published maps and institutional affiliations. 